\title{
Practices of Hospitality in a Sovereign World
}

\author{
Roxanne Lynn Doty ${ }^{1}$
}

The concept of hospitality occupies an important place in discussions of ethics, human rights, and social justice. This is especially the case in an increasingly globalized and interconnected world but one that is still characterized by strictly enforced territorial borders. This papers addresses the issue of "unconditional hospitality" as articulated by Jacques Derrida in such a world. I suggest that some instances of promigrant activism in the United States approach the kind of hospitality that Derrida speaks of that is free of conditions and that constitutes a radical shift in sensibility away from conventional views on sovereign territoriality. [Article copies available for a fee from The Transformative Studies Institute. E-mail address: journal@transformativestudies.org Website: http://www.transformativestudies.org (C2015 by The Transformative Studies Institute. All rights reserved.]

KEYWORDS: Hospitality, Sovereignty, Borders, Rights, Sanctuary.

\footnotetext{
${ }^{1}$ Roxanne Lynn Doty, Ph.D., is Associate Professor in the School of Politics and Global Studies. Her most recent book, The Law Into Their Own Hands: Immigration and the Politics of Exceptionalism, was published by the University of Arizona Press in 2009 and was awarded the Silver Book Award in 2010 by the Association of Borderland Studies. She is also the author of Anti-Immigrantism is Western Democracies-Statecraft, Desire, and the Politics of Exclusion published by Routledge, 2003 and Imperial Encounters: The Politics of Representation in North-South Relations published by University of Minnesota Press, 1996. She has published in International Studies Quarterly, Millennium: European Journal of International Relations, Review of International Studies, Alternatives, and International Political Sociology. Doty teaches courses on ethics and human rights in global politics, global inequality, and critical international relations theory. She serves on the editorial boards of International Political Sociology and Environment and Planning D: Society and Space. Roxanne Doty received her Ph.D. from the University of Minnesota in 1991. Address correspondence to: Roxanne Lynn Doty, Arizona State University, School of Politics and Global Studies, Lattie F. Coor Hall 6708, PO Box 873902, Tempe, Arizona 85287-3902; roxanne.doty@asu.edu.
} 